\title{
MITÄ PANDEMIAVUONNA TAPAHTUI?
}

\author{
PANDEMIA-TEEMANUMERO - OSA I
}

Tätä kirjoittaessa poikkeuksellinen vuosi 2020 on tulossa päätökseensä. Vielä vuosi sitten ajatus yhteiskunnallisesta ja yksilöllisestä varautumisesta pandemiaan tuntui kaukaiselta ajatukselta siitä huolimatta, että tutkijat ja terveysviranomaiset olivat läpi 2000-luvun varoittaneet eläimestä ihmiseen siirtyvän viruksen aiheuttaman maailmanlaajuisen pandemian olevan vain ajan kysymys. Koronaviruksen leviämisen alkushokin jälkeen yhteiskunnat mobilisoivat historialliset poikkeustilatoimet terveydenhuollon resurssien turvaamiseksi ja haavoittuvimpien ihmisryhmien suojelemiseksi. Vaikka kesä näyttäytyi joissakin maissa jo lähes paluulta normaaliin, loppusyksystä 2020 elettiin esimerkiksi suuressa osassa Eurooppaa pandemian toisen aallon myötä jälleen jyrkkien rajoitustoimien keskellä. Yleisissä puhetavoissa on korostunut tarve ennakoida, mutta tähän saakka niin tutkimus, politiikka kuin mediakin ovat lähinnä voineet vain pyrkiä pysymään pandemian kintereillä analyyseineen ja johtopäätöksineen. Keskeistä on ollut sopeutuminen: yhteiskuntien on täytynyt etsiä tilanteen vaatimia nopeita ratkaisuja samalla, kun ihmisten on ollut pakko muokata rajusti elämäänsä, työtään, opiskeluaan ja sosiaalisia suhteitaan.

Millaista on ollut elää pandemian keskellä? Vaikka pandemioista on valtavasti tietoa, niiden hallitsemattomuus tekee niistä oudon muutosvoiman. Pandemia purkaa saumattomiksi oletettuja sosiaalisia tapahtumaketjuja, joista muodostuu arjen, talouden ja politiikan "normaaliksi" kutsuttu yhteiskunnallinen rytmi. Normaaliin voi ja tulee luottaa, ja sen soljuvuutta pitävät yllä vallitsevat totuuskäsitykset siitä, mitä arjen, talouden tai politiikan kuuluu olla. Normaalia voikin katsella yhtäkkiä arvaamattoman etäältä, kun elämä käpertyy perhepiiriin, keskuspankit toimivat loputtomana rahalinkona ja poikkeustilapäätökset vyöryvät hallitusten pöydiltä toinen toisensa perään.

Juuri pandemian hallitsemattomuus tekee vaikeaksi pysähtyä käsittelemään kysymystä: Mitä vuonna 2020 oikein tapahtui? Toki on myös ilmeistä, että varmojen vastausten löytämisen vaatiminen olisi kohtuutonta pandemian yhä riehuessa ja sen pahimpien seurausten mahdollisesti ollessa vasta edessä. Samalla on selvää, että pääsemme tutkimuksellisesti käsiksi oikeastaan vasta pandemian alkusysäyksen, kevään 2020 tapahtumiin, reaktioihin ja vaikutuksiin. Kokonaisvaltainen kuva siitä, mikä todella muuttui suhteessa "normaaliin" onkin vasta hahmottumassa. Tästä huolimatta on kiinnostavaa ja tärkeää tutkia, mitä noiden alkukevään kriisihetkien aikana tapahtui, millaisia päätöksiä tehtiin ja millaisten perustelujen ja prosessien tuloksena. Entä miten yhteiskunnallinen ajattelu, tutkimus ja käsitteellinen työskentely reagoivat kevään kriisiin ja millaista tietoa ne kykenivät tuottamaan? 
Keskeinen pandemia-ajasta tehtäviä johtopäätöksiä ohjaava erottelu on se, onko kyse radikaalista katkoksesta, jopa kumouksesta, vai onko vuosi 2020 sittenkin vain osa jatkuvaa kehitystä: yhtäältä on puhuttu esimerkiksi pandemioiden lähes ikuisesta läsnäolosta länsimaisessa historiassa, toisaalta pandemian vielä riehuessa kapitalistista taloutta pyritään vivuttamaan takaisin totunnaiseen kehitysuomaan. Tästä näkökulmasta pandemia näyttäytyy hetkellisenä,joskin vakavan talouspudotuksen aiheuttaneena katkoksena. Koronakriisin alussa pandemia rinnastettiinkin toisinaan vallankumoukseen. Pandemiaa pidettiin kumouksena, joka osoittaa, että muutkin kumoukset ovat mahdollisia. Se panee ymmärtämään, että yhteiskuntaa voidaan ohjata voimallisesti haluttuun suuntaan, mikäli kyseessä on yhteiskunnallisen hyvinvoinnin turvaaminen. Vuosikausia vallinneet talousopit korvautuvat uusilla. Koronan opetuksilla selätämme ilmasto- ja biodiversiteettikriisinkin.

Onko todella näin? Oliko kumous sittenkin vain puolittainen? Oliko se edes sitä? Millainen on luvattu pandemianjälkeinen uusi normaali, jos se ei yhteiskunnallisen kokonaiskehityksen näkökulmasta lopulta juuri vanhasta normaalista eroa? Vaikuttaa siltä, että pandemia vaikutti ristiriitaisella tavalla: yhtäältä se muutti paljon, mutta samanaikaisesti elämä jatkui jotakuinkin entisellään. Tämän toteaminen ei vähennä pandemian tutkimisen mielekkyyttä, vaan päinvastoin: juuri tämä ristiriita tekee pandemiaan liittyvien odotusten ja seurausten tutkimisesta yhä tärkeämpää, ja vain sitä kautta tutkimuksen on mahdollista vaikuttaa kriisin aikana ja sen jälkeen tehtäviin yhteiskunnallisiin päätöksiin.

\section{TALOUS ENSIN?}

Koronaviruksen leviämisen aiheuttaman alkushokin jälkeen huomattiin, että pandemialla on yhteiskunnallisen elämän pysäyttämisen lisäksi myös toinen valtava voima: pandemian vaikutuksesta talouspoliittiset välttämättömyydet murtuivat tavalla, jolle on vaikea löytää vertailukohtaa modernien talouksien historiassa. Selvästikin rajoitustoimet aiheuttivat suuriin lamakausiin verrattavissa olevan tilanteen: talouden nopean supistumisen, massatyöttömyyden sekä kulutus- ja tuotantovirtojen ehtymisestä mahdollisesti seuraavan konkurssiaallon. Toisaalta vastaavankaltaista katkosta talouden normaaliin näyttävät edustavan historian niin sanotut"sotataloudet", joissa julkinen valta ohjasi yhteiskunnallista tuotantoa ulkoisen uhkan voittamiseksi ja yhteiskunnallisen turvallisuuden takaamiseksi. Kolmaskin vertailukohta on löydettävissä: talous on pysähtynyt kevään 2020 kaltaisesti laajamittaisissa organisoiduissa protesteissa, esimerkiksi yleislakoissa. Virus ja sota tulkitaankin usein yhteiskuntien ulkoisiksi uhkiksi, vihollisiksi, joiden edessä kansantaloudet pysäytetään ja uudelleen mobilisoidaan kansalaisten turvallisuuden turvaamiseksi. Lakko taas pysäyttää talouden sen sisältä käsin, yhteiskunnallisista syistä.

Yhteistä näille tapahtumille - pandemialle, sodalle ja lakolle - on, että lähtökohtaisestikin kovin yksipuolinen ajatus "markkinoiden" kyvystä ylläpitää yhteiskunnallista järjestystä kyseenalaistuu ja taloudellisen toiminnan mahdollisuudet, voimasuhteet ja päämäärät näyttäytyvät normaaliin verrattuna hyvin erilaisessa valossa. Keväällä 2020 talouspolitiikan paradigma muuttui erityisesti kahdella taval- 
la: yhtälätä keskuspankit ottivat entistä vahvemman roolin kapitalistisen talouden perustoiminnan ylläpidossa ja aiempi, lähes kyseenalaistamaton suhtautuminen julkisvelkaan koki merkittävän kolauksen valtioiden vaipuessa historiallisiin alijäämiin. Kun pandemia runteli sä̈littä kaikkia kansantalouksia, voitiin velkaan suhtautua uudella tavalla, ja harva enää todella puolusti talouskuria ja rakenteellisia sopeutuksia, vaikka pandemiatoimet paisuttivat historiallisesti valtioiden menoja. Tämä näkyi konkreettisesti esimerkiksi Suomen hallituksen linjauksissa, kun pandemianjälkeisen julkisen taloudenpidon kiintotähdiksi ei enää nimetty edeltävien linjausten tapaan kaavamaisia työllisyystavoitteita tai kestävyysvajetta vaan oleellisemmaksi tekijäksi käsitettiin julkisen velkasuhteen kasvun taittaminen kuluvan vuosikymmenen loppuun mennessä.

Vuoden 2008 finanssikriisin jälkimainingeissa ja eurokriisin puhjetessa julkista velkaantumista hoidettiin talouskurilla tuhoisin sosiaalisin ja poliittisin seurauksin. Ainakin pandemian ensimmäisen aallon yhteydessä näytti siltä, että talouden kriisiytymiseen suhtauduttiin toisenlaisella tavalla, kuin mihin olemme viimeisen reilun kymmenen vuoden aikana tottuneet. Mikään ei kuitenkaan itsessään takaa, etteikö velan ja talouskurin liitto palaa talouspolitiikan keskeiseksi ohjuriksi pandemian helpottaessa. Erityisesti äärioikeiston valtavirtaistaessa ja salonkikelpoistaessa politiikkaansa sen erääksi keskeiseksi piirteeksi on muotoutumassa tiukka suhtautuminen julkistalouteen ja sosiaalipolitiikkaan - enää sosiaalietuuksia eivät kuluta vain maahanmuuttajat vaan kaikki köyhät ja toimettomat. Esimerkiksi perussuomalaisten viimeaikaisissa talouslinjauksissa Halla-aho profiloi joukkoaan valtionhoitajapuolueeksi juuri tiukalla talouslinjalla. Kun pandemian jälkeisen talouspolitiikan suunnasta kamppaillaan, onkin täysin mahdollista kuvitella tilanne, jossa keskustaoikeisto hyväksyy tiukan maahanmuuttopolitiikan ja vesittyneen ilmastopolitiikan ja yhteinen sävel löytyy jälleen talouskurista, tällä kertaa äärioikeiston kylkeen liimautuneena.

\section{TEHDÄÄNKÖ KAIKKI VAI EI?}

Yksi tärkeä pandemian nostattama kysymys on, miksi ilmastonmuutoksen ja biodiversiteettikadon kaltaiset ympäristöongelmat eivät ole saaneet aikaan vastaavaa yhteiskunnallista reaktiota, vaikka siihen olisi ollut jo kauan täysin ilmeiset perustelut. Miten ilmastonmuutoksen hätätila eroaa siitä tilanteesta, jonka pandemia tuotti? Toki näihin kysymyksiin on helppo lähteä luettelemaan syitä, joista keskeisin on, että pandemia uhkasi välittömästi ja suoraan kaikkia ihmisiä kaikkialla maailmassa. Pandemian vaikutukset tuntuivat nyt todella läntisten yhteiskuntien ytimissä eikä vain kaukana globaalissa etelässä kuten ympäristökriisien pahimpien seurausten osalta jo tällä hetkellä on.

Vaikka molempien hätätilojen todellisuus on aivan yhtä ilmeinen, pandemian kohdalla toimet, joita ilmastonmuutoksen pysäyttämiseksi on ehditty vaatia jo vuosia, tapahtuivat kuin itsestään. Miten tämä on mahdollista? Ilmastonmuutoksen ja kasvavassa märin myös elonkirjon osalta vallitseva diskurssi on ollut kaksijakoinen: vaatimus tehdä kaikkensa tunnustetaan, mutta kaikkea ei missään nimessä ole tehty 
tai sitä ei ole edes vakavasti harkittu, koska talous on vaikuttanut kaiken toiminnan suhteen ensisijaiselta ja ainoalta todelliselta puitteelta. Pandemia vaikutti tuottavan uuden tietoisuuden siitä, miten talouspoliittinen niukkuus ei olekaan "totta".

Pandemiatilanteesta on ilmastonmuutoksen tavoin löydettävissä myös laajempi taso, joka osoittaa, että myöskään zoonoottisten virusten suhteen kaikkea ei todellakaan ole tehty. Pandemia syntyi todennäköisesti sellaisten vaikutusketjujen tuloksena, joissa ihmisen toiminnalla on aivan ilmeinen osansa. Ekstraktivistisen kapitalismin ytimessä olevan sademetsien tuhoamisen voi nähdä vaikuttaneen siihen, että koronavirus pääsi kehittymään ja myöhemmin siirtymään ihmiseen sademetsien eläimistön elinympäristöjen tuhoutuessa. Metsätuhot sekä massiivinen, teollisen mittakaavan tehoeläintuotanto ovat todennäköisesti keskeisiä vaikuttimia myös tuleville pandemioille.

Voikin sanoa, että pandemiaa on käsitelty pitkälti niin, että viruksesta on tehty yhteiskunnallisen taistelun vihollinen, eräänlainen syntipykki, jota syyttämällä on voitu jättää käsittelemättä sellainen yhteiskunnallinen ja poliittinen taso, joka perimmiltään edesauttaa SARS-CoV-2:n kaltaisten virusten syntymistä. Purkamalla syntipukki-asetelman joudumme kääntämään kivuliaasti katseemme omaan toimintaamme ja pohtimaan talouden täydellistä uudelleen määrittelyä.

Vaikka pandemiakriisin yhteiskunnallisuudesta on puhuttu paljon, vaikuttaa siltä, että sen perusteellinen kytkös vallitseviin yhteiskunnallisiin rakenteisiin vaatii vielä paljon tutkimusta ja rautalankaa. Oleellista olisi huomata, että kyse on kriisistä, joka pahentaa ja korostaa jo aiemmin rakentuneita kapitalismin, hoivatyön, rasismin ja ilmastonmuutoksen kriisejä. Judith Butlerin (2020) mukaan globaali pandemia on paljastanut"kapitalistisen koneiston ytimessä toimivan kuolemanvietin”. Yhteiskunnan avaaminen talouden vuoksi keskellä pandemiaa on päätös, jonka hintana on ihmisten joutuminen hengenvaaraan. Tämä koskettaa tietysti suoraan niin sanottujen riskiryhmäläisten henkeä, mutta myös matalapalkkaisissa ja epävarmoissa palvelu- ja hoiva-alan ammateissa työskenteleviä, usein myös rasismin kohteeksi joutuvia ihmisiä.

Näkökulma on hyvä laajentaa globaaliksi. Esimerkiksi Achille Mbembe (2020) on korostanut, että pandemiakriisi on nähtävä osana jatkumoa, jossa kolonialistisia tendessejä jatkava kapitalistinen tuotanto ulkoistaa seurauksensa. Siten pandemian seurausten ohella ilmastonmuutos on hinta, jonka vallitsevasta, neutraalina ja normaalina pidetystä, globaalista tuotannosta on maksettava äärimmäisen epäoikeudenmukaisesti jakautuvalla tavalla. Myös Catherine Malabou (2020) on kirjoittanut, että pandemian uhrit voi todella nähdä "uhreina" sanan siinä merkityksessä, jossa se tarkoittaa jonkin elämän tuhoamista tietyn päämäärän vuoksi kuten uhraamisessa. Minkä askeleen historia koronapandemian jälkeen ikinä ottaakaan niin jokainen edistyksenä pidetty askel tapahtuisi siten sen "ansiosta”, että tietyt elämät uhrattiin kriisin selättämiseksi. 


\section{PANDEMIAN TUTKIMISEN}

\section{MONITIETEINEN HAASTE}

Pandemiatilanteessa on muihin viimeaikaisiin kriiseihin nähden myös se ero, että siinä tieteen merkitys on erityisen oleellinen: esimerkiksi jo pelkkä "näyttöön perustuvan päätöksenteon" rooli nykyisessä politiikassa tuli koronaviruksen uhan edessä aivan uudella tavalla keskeiseksi ja nosti esiin monta perustavanlaatuista kysymystä. Yhtäältä pandemia pakotti hyväksymään tieteen uudella tapaa suurten yhteiskunnallisten päätösten perusteeksi - siis ikään kuin politiikan ei-poliittiseksi perustaksi. Toisaalta vaatimus tieteellisestä paikkansapitävyydestä oli ennennäkemättömän vaikea siksi, että tilanne syntyi niin nopeasti ja pandemian etenemisen lainalaisuuksista, sen syy-seuraus-suhteista, oli varsin vähän nopeasti sovellettavaa tietoa. Kuinka luottaa tutkittuun tietoon nopeiden valintojen tilanteessa, jossa tutkimus itsekin joutuu myöntämään olevansa kovin keskeneräistä ja sen perustavien lähtökohtien olevan vasta muotoutumassa?

Yhteiskunnallisen tutkimuksen kannalta vaikuttaa olennaiselta, että pandemia alleviivaa ja tuo uudella tavalla esiin jännitteen, joka usein vallitsee yhteiskunnallisen keskustelun kahden tason välillä. Tutkimuksen näkökulmasta asiaa voi kuvata ensinnäkin sen radikaalin eron kautta, jota tuottaa metodinen valinta sen välillä tehdäänkö tutkimusta niin sanotusti alhaalta vai ylhäältä päin. Pandemiatilanne näyttää kovin erilaiselta, kun sitä katsotaan ylhäältä, siis tilanteen ja siinä elävien ihmisten hallitsemisen ja valtiollisen järjestyksen näkökulmasta, kuin jos sitä tarkastellaan eletyn elämän, kokemusten ja tunteiden tasolta.

Toinen näkökulma jännitteeseen on, kuinka yhteiskunnallisen ajattelun käsitteellinen - ja tietyssä mielessä yhteiskuntafilosofinen - taso suhteutuu empiiriseen ja luonnontieteelliseen tietoon. Kyse on jännitteestä, joka on leimannut laajemminkin esimerkiksi viimeaikaista keskustelua antroposeenista sekä humanismin ja posthumanismin välisestä kitkasta (keskustelua molemmista teemoista on viime vuosina käyty ahkerasti myös Tiede $\Xi$ edistyksen sivuilla). Rajusti yksinkertaistaen voi sanoa, että pandemiatilanne on paljastanut sen, kuinka filosofinen keskustelu yhteiskunnasta ja sen ilmiöistä on usein sisällöiltään ja logiikaltaan sellaista, että sen olisi aivan hyvin voinut käydä jo ennen tarkastelun alla olevien ilmiöiden tapahtumista. Tämä piirre tuli voimakkaasti esiin kevälllä, kun pandemiatilanteen ensimmäisinä kuukausina keskusteltiin valtavasti poikkeustilan käsitteestä ja siitä mitä sen käyttöönotto koronaviruksen takia tarkoittaa.

Pandemiaa koskeva monitieteellinen tutkimus romuttaa unelman humanismin sankarillisesta ihmisestä. Yhteiskunnallinen ajattelu on joutunut kohtaamaan tilanteen, jossa kaikkein polttavimpien kysymysten tarkastelu ei voi lähteä liikkeelle puhtaista käsitteistä tai omista kokemuksista vaan erilaisista tosiasioiden joukoista, jotka tuottaa niin luonnontiede kuin empiirinen tutkimustyö. Keskiössä on kyllä elämää, mutta sen suhteen rajanvedot inhimillisen ja ei-inhimillisen välillä ovat kovin mielivaltaisia.

Erityisesti antropologisen tutkimuksen jo ennen koronapandemiaa tarjoama opetus on, että globaali kapitalismi elä monien sellaisten toimintatapojen varas- 
sa, joissa sosiaalisten ongelmien ja luonnonvarojen riistämisen lisäksi tuotetaan edellytykset eläinperäisten virusten kehittymiselle ja niiden siirtymiselle ihmiseen. Esimerkiksi voi ottaa antropologi Christos Lynteriksen teoksen Human Extinction and the Pandemic Imaginary (2019), jossa hän jo ennen koronapandemian puhkeamista esitti, että modernit yhteiskunnat täysin inhimillisiksi käsitettyine alueineen ovat läpikotaisin ja perustavalla tavalla kytköksissä planeettamme prosesseihin, sen kasvi- ja eläinkuntaan. Tämän kytköksellisyyden ohittaminen ei ole vain joidenkin tieteentekijöiden tai paradigmojen satunnainen virhe vaan syvästi läntisten yhteiskuntien ja järjestelmien ytimeen kirjautunut piirre.

Monitieteisyys on nimi empiiristen ja luonnontieteiden uudelleen muotoillulle suhteelle yhteiskunnalliseen ajatteluun ja teorianmuodostukseen. Kaikesta nykyisestä ajanmukaisuudestaan ja jopa muodikkuudestaan huolimatta monitieteisyys ei ole ollut viimeaikaisen länsimaisen ajattelun perinteen piirre - tai ainakin viime vuosikymmenten yhteiskuntatiedettä on vaivannut tietty menneiden materialismien trauma. Voisi nimittäin väittää, että aidosti monitieteiset tutkimusotteet tulivat - tai palasivat - yhteiskuntatieteiden ytimeen toden teolla vasta vuosituhannen vaihteessa ilmastonmuutosta ja esimerkiksi antroposeenia koskevien keskustelujen kautta: yhteiskuntatieteiden pitkään vaalima epäilys kaikkea objektiivisena esitettyä tietoa kohtaan on joutunut koetukselle, kun luonnontieteelliseltä pohjalta esitetyt maapallojärjestelmän tilaa koskevat tiedot puhuvat omaa vastaansanomatonta kieltään.

Yhteiskunnallisen keskustelun yhteys empiiriseen tietoon ja monitieteiseen tutkimusotteeseen onkin piirre, joka yhdistää ilmastonmuutosta ja pandemiatilannetta. Jos tätä suhdetta kutsuu edellä kuvatulla tavalla käsitteellisen ja empiirisen väliseksi jännitteeksi, niin voisi sanoa että pandemian kaltaiset tapahtumat ikään kuin kääntävät tämän jännitteen navat: suurten historiallisten linjojen ja yhteiskuntien järjestystä perustelevien käsitteiden sijaan yhteiskunnallisen keskustelun ytimeen pakottautuu ilmiöiden tarkka ja yksityiskohtainen jäljittäminen ja kuvaaminen. Tämä käänne ei merkitse mitään yksinkertaista positivistista uskoa neutraaliin tieteeseen vaan tiettyä materiaalisen ja ilmiöiden tason uudenlaista vakavasti ottamista: on jätettävä hetkeksi sivuun perityt ja ennakkoon kiinnitetyt oletukset siitä, miten tieteen löytämät tosiasiat kytkeytyvät laajempaan yhteiskunnallisen ajattelun käsitteistöön, ja ajateltava tämä kytkös uudelleen kulloisenkin tilanteen vaatimalla tavalla. Näin voisi ajatella siksi, että yhteiskunnallisella ajattelulla on viime vuosikymmeninä ollut taipumus aliarvioida "kovien" tosiasioiden kelpoisuutta yhteiskunnallisten ongelmien kuvaamisessa ja sitä, kuinka yhteiskunnallinen muutos voisi olla niihin sidottua ja saada niistä vauhtia.

\section{TEEMANUMERO MONITIETEISEN}

\section{TUTKIMUSOTTEEN JÄNNIT'TEISSÄ}

Käsissäsi oleva numero on Tiede E edistyksen Pandemia-teemakokonaisuuden ensimmäinen osa. Kokonaisuuden toisen osan julkaisemme numerossa 4/2020 vuodenvaihteen jälkeen. Kaksiosainen Pandemia-kokonaisuus tarjoaa monipuolisen näköalan siihen, mitä vuonna 2020 tapahtui. Numeroiden tutkimusartikkelit ja 
puheenvuorot tutkivat pandemian taustoja, seurauksia ja tehtyjä päätöksiä monista eri näkökulmista ja erilaisin tutkimusottein. Pandemiaan pureudutaan niin ylhäältä kuin alhaalta päin samalla, kun tarkasteluun tulee väistämättä myös näiden tasojen jännitteet ja välityssuhteet.

Kaksiosaisen teemanumeron tekstikokonaisuuden ominainen piirre on monitieteellisyys, jonka pandemian kaltaiset tilanteet näyttäisivät nostavan muuallakin esiin. Monitieteellisyydessä ei ole kuitenkaan kyse mistään kevyestä moninaisuudesta ja sen kiinnostavuudesta ja rikkaudesta sinänsä. Sen sijaan Pandemia-numeron tekstien tuottama käsitys lähtee siitä, että rakenteellisten ja systeemisten kysymysten tarkastelu vaatii kovien tosiasioiden esiinnostamista, niiden törmäyttämistä toisiinsa ja uusia käsitteitä niiden välisten yhteyksien ja yhteensopimattomuuksien ymmärtämiseksi.

Käsillä olevan numeron tutkimusartikkeleissa Stefano Canali ja Saana Jukola tarkastelevat näyttöön perustuvan politiikan jännitteitä. Hanna Kara ja Eveliina Heino pureutuvat pandemian vaikutuksiin lapsiperheiden muuttuneen tilanteen kautta. Tuukka Brunila ja Mattias Lehtinen analysoivat valmiuslakien yhteydessä tuotettua sotaretoriikkaa affektiteorian näkökulmasta.

Numeron neljä puheenvuoroa puolestaan lähestyvät selviytymistä ja mukautumista pandemian poikkeusoloihin kahdella tasolla. Yhtäältä kotien ja perheiden, toisaalta instituutioiden tasolla pandemia-aikaa nimittäin luonnehtii tietty yhteinen rakenteellinen piirre: pandemiaa ei kohdattu tyhiössä tai kaiken muuttavana mullistuksena. Sen sijaan sitä vastustettiin ja siihen mukauduttiin vanhojen rakenteiden mukaisesti, mikä korosti näiden rakenteiden yleisempää ja pandemiaa edeltänyttä merkitystä, niiden toimivuutta ja toimimattomuutta. Perheissä uusintavan työn jännitteet korostuivat ja luokkasuhteet tulivat näkyviksi. Samalla juuri hoivatyölle välttämättömän siirtolaistaustaisen työvoiman rakenteellisesti heikko asema tuli jälleen kerran esiin. Valtiollisella tasolla koronapandemian torjunta ja sen seuraukset esimerkiksi hyvinvointivaltion takaamiin valmiuksiin, ennakointiin ja turvallisuuteen sekä työmarkkinoihin hahmottuivat - hyvässä ja pahassa - olemassaolevien instituutioiden ja niiden rajoitteiden puitteissa.

NUMERON TOIMITTAJAT ARI KORHONEN, ALEKSI LOHTAJA JA TERO TOIVANEN

VIITEET

Butler, Judith (2020) "On COVID-19, the Politics of Non-violence, Necropolitics, and Social Unequality".https://www.versobooks.com/blogs/4807-judith-butler-on-covid-19-the-politics-of-nonviolence-necropolitics-and-social-inequality Viitattu 15.12.2020.

Lynteris, Christos (2019) Human Extinction and the Pandemic Imaginary. Framing Animals as Epidemic Villains. Routledge, London.

Malabou, Catherine (2020) "Contagion: State of Exception or Erotic Excess? Agamben, Nancy, and Bataille". Crisis and Critique 7:3, 220-226.

Mbembe, Achille (2020) "The Universal Right to Breathe”. https://critinq.wordpress.com/2020/04/13/ the-universal-right-to-breathe/ Viitattu 15.12.2020. 